\title{
PENGARUH INSENTIF, DISIPLIN KERJA, DAN KOMUNIKASI TERHADAP KINERJA KARYAWAN BAGIAN SEWING PT. PELITA TOMANGMAS KARANGANYAR
}

\author{
Yeri Yuliyanti ${ }^{1}$ Istiatin $^{2}$, Ida Aryati $^{2}$ \\ ${ }^{1}$ Mahasiswa Manajemen Fakultas Ekonomi Universitas Islam Batik Surakarta \\ ${ }^{2}$ Dosen Fakultas Ekonomi Universitas Islam Batik Surakarta \\ Email: yeriyuliyanti49@gmail.com
}

\begin{abstract}
The purpose of this research are: 1) To determine the effect of incentive, dicipline, and comunication simultaneously on employee performance sewing division PT.Pelita Tomangmas Karanganyar. 2) To determine the effect of incentive, dicipline, and comunication on employee performance sewing division PT.Pelita Tomangmas Karanganyar.

Data collection method used is the method of questionnaire / questionnaire to 50 employees as respondents. Sampling technique used is random sampling method convenionce sampling. Data analysis methods used include: test instrument (validity and reliability), hypothesis testing (multiple linear regression analysis, t-test, $\mathrm{f}$ and the coefficient of determination (R2).

Results Descriptive analysis showed that most respondents gender female (90\%). All data from the questionnaires have passed the test instrument. For testing $\mathrm{f}$ test result that the value of $\mathrm{F}(46.710)>\mathrm{F}$ table $(2,81)$ with a probability of $0.000(\mathrm{p}<0.05)$. This means Fhitung in the region of Ho rejected, which means a significant difference between the independent variable (incentive, dicipline, and comunication) simultaneously on the dependent variable (employee performance). From the results of the $t$ test result incentive have a significant positive effect on an individual basis to variable employee performance. This is evident from tcount (5.697) $>\mathrm{t}$ table (2.013) with a significance value $<\alpha(0.05)$. Variable dicipline are also significant positive effect on employee performance. This is because tcount (2.164)> t table (2.013) with a significance value $<\alpha(0.05)$. comication is also significant positive effect on employee performance. This is because tcount $(2,551)>t$ table (2.013) with a significance value $<\alpha(0.05)$. The results of the analysis in this study was obtained R2 values of $0.753(75.3 \%)$. This means that the independent variable (incentive, dicipline, and comunication) able to contribute $75.3 \%$ influence on the dependent variable (employee performance). While the rest of $24.7 \%$ is influenced by other variables outside of this study as a leadership, compensation, organisational culture, working environment, etc.
\end{abstract}

Keywords: Incentive, dicipline, comunication, employee performance 


\section{PENDAHULUAN}

\section{Latar Belakang Masalah}

Setiap Perusahaan tentu mengharapkan karyawannya bekerja dengan baik dan produktif, namun hal tersebut tidak akan mudah dicapai tanpa adanya pengelolaan sumberdaya manusia secara professional. Salah satu faktor yang dapat meningkatkan produktifitas karyawan yaitu kinerja karyawan. Kinerja seorang karyawan merupakan hal yang bersifat individual, karena pegawai memiliki kemampuan yang berbeda-beda dalam mengerjakan tugasnya. Kinerja karyawan secara langsung berpengaruh terhadap citra perusahaan dimata masyarakat luas. Kinerja karyawan yang baik menentukan pencapaian produktifitas perusahaan. Namun faktanya tidak semua kayawan memiliki kinerja yang bagus, masih ada karyawan yang memiliki kinerja yang tidak sesuai dengan harapan perusahaan.

Kinerja karyawan merupakan hal yang sangat penting dan ini sebagai tantangan tersendiri untuk perusahaan dalam mengelola sumber daya manusia, karena keberhasilan suatu perusahaan tergantung pada sumber daya manusia yang berkualitas. Tujuan perusahaan tidak akan tercapai tanpa peran aktif dari karyawan. Menurut Mangkunegara (2000: 45) istilah kinerja berasal dari kata job performance atau actual performance (prestasi kerja atau prestasi sesungguhnya yang dicapai seseorang) yaitu hasil kerja (output) secara tugasnya sesuai dengan tanggung jawab yang diberikan kepadanya. Kinerja perusahaan/ instansi yang buruk dapat disebabkan oleh penurunan kinerja pegawai, hal ini terlihat ketika pegawai tidak dapat menyelesaikan pekerjaan dengan target dan waktu yang ditentukan oleh perusahaan/ instansi.

Mengatur karyawan bukanlah suatu hal yang mudah, sebab para karyawan memiliki perasaan, keinginan, status, latar belakang, dan sebagainya oleh sebab itu diperlukan strategi khusus untuk menangani masalah karyawan. Salah satu usaha untuk meningkatkan kinerja karyawan diantaranya adalah dengan memberikan insentif. Insentif merupakan salah satu jenis penghargaan yang dikaitkan dengan penilaian kinerja karyawan. Semakin tinggi kinerja karyawan, semakin besar pula insentif yang akan diberikan oleh perusahaan. Pemberian insentif dilakukan untuk meningkatkan kinerja karyawan terhadap output yang dihasilkan.

Pemberian Insentif kepada karyawan akan berdampak terhadap semangat dalam mencapai prestasi yang baik dan memberikan kinerja yang besar bagi perusahaan. Sehingga setiap karyawan termotivasi untuk memberikan kontribusi yang lebih bagi perusahaan dalam mencapai tujuannya. Menurut Hariandja (2005: 265) insentif merupakan bentuk pembayaran langsung yang dikaitkan dengan kinerja dan Gain Sharing yang diartikan sebagai pembagian keuntungan bagi pegawai akibat peningkatan produktivitas atau penghematan biaya.

Karyawan memiliki peranan yang penting dalam menentukan pengembangan kualitas kerja di setiap perusahaan. Salah satu unsur yang mempengaruhi kinerja karyawan adalah disiplin, tanpa adanya disiplin dari karyawan maka segala kegiatan yang akan dilakukan hasilnya pasti 
kurang memuaskan dan tidak sesuai dengan yang diharapkan. Hal ini dapat mengakibatkan kurangnya pencapaian sasaran dan tujuan perusahaan dan juga dapat menghambat jalannnya program yang sudah dibuat oleh perusahaan. Jika dilihat secara nyata kedisiplinan karyawan memegang peranan yang penting dalam pelaksanaan pekerjaan sehari- hari. Pegawai yang mempunyai tingkat kedisiplinan yang tinggi akan tetap bekerja dengan baik sekalipun tidak diawasi oleh atasan. Penerapan disiplin dalam perusahaan bertujuan agar semua karyawan dalam perusahaan tersebut bersedia dengan sukarela menaati semua tat tertib yang berlaku tanpa adanya paksaan.

Pencapaian tujuan perusahaan dan pelaksanaan manajemen perusahaan akan menjadi efektif dan efisien apabila komunikasi antara pimpinan dengan bawahan serta komunikasi antar sesama karyawan berjalan dengan baik. Komunikasi merupakan penyampaian informasi dari seseorang kepada orang lain, pertukaran ide dan informasi dua arah yang menuju tercapainya pengertian bersama (Thoha, 2004: 78). Komunikasi tersebut akan berkaitan dengan kebijakan, strategi dan norma- norma yang ada di perusahaan. Harapannya dengan adanya komunikasi ini akan memperlancar tugas dan kewajiban karyawan, maksud dan tujuan perusahaan tersampaikan dengan baik, serta karyawan mengerti apa dan bagaimana yang diinginkan oleh perusahaan sehingga dengan komunikasi yang terjalin dengan baik akan mempercepat tercapainya tujuan perusahaan.

PT. Pelita Tomangmas Karanganyar sebagai perusahaan yang besar dengan jumlah karyawan yang banyak pasti mempunyai banyak tugas yang harus dikerjakan dalam pelaksanaan operasional perusahaan guna mencapai tujuan perusahan.Untuk dapat mencapai tujuan perusahaan dibutuhkan kinerja karyawan yang bagus, semakin tinggi kinerja karyawan maka tujuan dari perusahaan akan lebih mudah dicapai. Banyak faktor yang dapat mempengaruhi kinerja karyawan diantaranya tidak tepat waktu dalam penyelesaian pekerjaan, menurunnya disiplin kerja, pengaruh lingkungan, budaya organisasi dan komunikasi yang tidak berjalan dengan lancar.

Sehubungan dengan hal tersebut diatas kemudian timbul pemikiran bagaimana keseluruhan faktor tersebut saling berkesinambungan mempengaruhi kinerja karyawan, untuk itu diperlukan adanya suatu penelitian yang dapat membuktikan bahwa faktor - faktor tersebut mempunyai pengaruh terhadap kinerja karyawan. Atas dasar latar belakang masalah tersebut maka dipandang layak untuk meneliti dengan judul Pengaruh Insentif, Disiplin Kerja, dan Komunikasi Terhadap Kinerja Karyawan Bagian Sewing PT. Pelita Tomangmas Karanganyar.

\section{Rumusan Masalah}

Berdasarkan latar belakang yang dikemukakan diatas, maka secara terperinci masalah yang akan diteliti dan dibahas adalah sebagai berikut:

1. Apakah Insentif, disiplin kerja, dan komunikasi berpengaruh secara simultan terhadap kinerja karyawan bagian sewing PT. Pelita Tomangmas Karanganyar? 
2. Apakah insentif berpengaruh terhadap kinerja karyawan bagian sewing PT. Pelita Tomangmas Karanganyar?

3. Apakah disiplin kerja berpengaruh terhadap kinerja karyawan bagian sewing PT. Pelita Tomangmas Karanganyar?

4. Apakah komunikasi berpengaruh terhadap kinerja karyawan bagian sewing PT. Pelita Tomangmas Karanganyar?

\section{Tujuan Penelitian}

Tujuan penelitian yang dilakukan di PT. Pelita Tomangmas Karanganyar adalah sebagai berikut:

1. Untuk mengetahui pengaruh secara simultan insentif, disiplin kerja dan komunikasi terhadap kinerja karyawan bagian sewing PT.Pelita Tomangmas Karanganyar..

2. Untuk mengetahui pengaruh insentif terhadap kinerja karyawan bagian sewing PT.Pelita Tomangmas Karanganyar.

3. Untuk mengetahui pengaruh disiplin kerja terhadap kinerja karyawan bagian sewing PT.Pelita Tomangmas Karanganyar.

4. Untuk mengetahui pengaruh komunikasi terhadap kinerja karyawan bagian sewing PT.Pelita Tomangmas Karanganyar.

\section{TINJAUAN PUSTAKA}

\section{Kinerja Karyawan}

Kinerja adalah hasil kerja secara kualitas dan kuantitas yang dicapai oleh seorang pegawai dalam melaksanakan tugasnya sesuai dengan tanggung jawab yang diberikan kepadanya (Mangkunegara
2007: 67). Kinerja sering kali dipikirkan sebagai pencapaian tugas, dimana istilah tugas sendiri berasal dari pemikiran aktivitas yang dibutuhkan oleh pekerja. Karena kinerja pegawai merupakan suatu tindakan yang dilakukan pegawai dalam melaksanakan pekerjaan yang dilakukan perusahaan (Sutrisno, 2009: 95).

Suatu perusahaan/ organisasi tentunya mempunyai tujuan yang harus dicapai, dalam jangka pendek maupun jangka panjang. Untuk mencapainya dibutuhkan kinerja perusahaan/organisasi yang baik. Kinerja perusahaan erat kaitannya dengan kinerja karyawan. Jika kinerja karyawan baik, tentunya akan berdampak positif terhadap kinerja perusahaan.

Kinerja menurut Simamora (2005: 327) adalah tingkat mana karyawan mencapai persyaratan pekerjaan. Sedangkan pengertian kinerja menurut Robbins (2009: 258) adalah merupakan ukuran dari sebuah hasil. Dari pengertian diatas dapat disimpulkan bahwa kinerja karyawan merupakan hasil kinerja yang telah dicapai setiap karyawan, sehingga memberikan ketertiban terhadap perusahaan.

Tujuan penilaian kinerja menurut Robbins (2009 : 259) adalah sebagai berikut :

a) Untuk mengambil keputusan personjalia secara umum, sehingga dapat memberikan informasi yang berhubungan dengan pengambilan keputusan yang penting dalam hal promosi, transfer/pemberhentian.

b) Memberikan penjelasan tentang pelatihan dan pengembangan yang dibutuhkan. 
c) Dapat dijadikan sebagai kriteria untuk program seleksi dan pengembangan yang disahkan

\section{Insentif}

Insentif merupakan salah satu jenis penghargaan yang dikaitkan dengan penilaian kinerja pegawai. Semaki tinggi kinerja pegawai, semakin besar pula insentif yang diberikan oleh perusahaan. Pelaksanaan system insentif dilakukan untuk meningkatkan kinerja pegawai terhadap output yang dihasilkan, seperti yang dikemukakan para ahli, diantaranya:

Jiwo wangso dan Kartanto (2003: 101) mengemukakan "Insentif merupakan elemen atau balas jasa yang diberikan secara tidak tetap atau bersifat variabel tergantung pada kondisi pencapaian prestasi kerja karyawan. MenurutHariandja (2005: 265) bahwa "Insentif merupakan bentuk pembayaran langsung yang dikaitkan dengan kinerja dan Gain Sharing dan diartikan sebagai pembagian keuntungan bagi pegawai akibat peningkatan produktivitas atau penghematan biaya."

Berdasarkan uraian diatas dapat dibuat kesimpulan bahwa yang dimaksud dengan Insentif adalah suatu Penghargaan dalam bentuk uang yang diberikan oleh pihak pimpinan kepada pegawai agar mereka bekerja dengan motivasi yang tinggi, berprestasi dalam mencapai tujuan organisasi atau diluar gaji sebagai pengakuan terhadap prestasi kerja dan kontribusi pegawai kepada perusahaan/ instansi.

Jenis-jenis Insentif dalam suatu perusahaan atau instansi harus dituangkan secara jelas sehingga dapat diketahui oleh pegawai dan oleh perusahaan tersebut dapat dijadikan kontribusi yang baik untuk dapat menambah gairah kerja bagi pegawai yang bersangkutan.

Menurut ahli manajemen sumber daya manusia Sondang P. Siagian (2002: 268), jenis-jenis insentif tersebut adalah:

a. Piece Work

Piece work adalah teknik yang digunakan untuk mmendoronng kinerja kerja pegawai berdasarkan hasil pekerjaan pegawai yang dinyatakan dalam jumlah unit produksi

b. Bonus

c. Komisi

d. Insentif bagi eksekutif

e. Kurva "kematangan"

f. Rencana Insentif Kelompok

Jelas bahwa insentif yang memadai akan mendorong semangat dan gairah tenaga kerja pegawai, sehigga pegawai akan terus menjaga dan meningkatan hasil kerjanya pada akhirnya akan meningkatka keuntungan itu sendiri dalam mencapai tujuan dan sasaran yang ditetapkan, sehingga instansi dan pegawai diharapkan lebih solid dalam membangun kebersamaan menuju kemajua perusahaan atau instansi.

\section{Disiplin Kerja}

Setiap perusahaan pasti memiliki standar perilaku yang harus dilakukan dalam kaitannya dengan pekerjaan, baik secara tertilis maupun tidak dan juga menginginkan karyawannya untuk menaatinya sebagai upaya untuk meningkatkan produktifitas perusahaan. Namun kondisi dilapangan banyak karyawan yang kurang disiplin, oleh karena itu peningkatan kedisiplinan menjadi bagian yang penting dalam manajemen sumber daya manusia. 
Hasibuan dalam Erza (2010: 56) berpendapat bahwa kedisiplina adalah kesadaran dan kesediaan seseorang menaati semua peraturan perusahaan dan normanorma sosial yang berlaku. Disiplin pada hakekatnya adalah kemampuan untuk mengendalikan diri dalam bentuk tidak melakukan suatu tindakan yang tidak sesuai dan bertentangan dengan sesuatu yang telah ditetapkan. Sedangkan disiplin kerja merupakan kemampuan seseorang untuk secara teratur, tekun secara terus- menerus dan bekerja sesuai dengan aturan yang berlaku dengan tidak melanggar aturanaturan yang sudah ditetapkan (Aritonang, 2005: 3-4).

Dalam menjalankan aktivitasnya, setiap perusahaan tidak luput dari tingkat kedisiplinan karyawannya dalam menciptakan ketertiban dan kelancaran dalam bekerja. Oleh sebab itu setiap perusahaan harus memiliki standar dan ketentuan yang harus ditaati dan dipenuhi oleh karyawannya.

Dalam organisasi perusahaanada beberapa macam jenis disiplin, diantaranya:

1. Disiplin Preventif

Yaitu suatu kegiatan yang dilaksanankan untuk mendorong para karyawan agar mengikuti standar dan aturan, sehingga penyelewengan dapat dicegah. Sasarannya untuk mendorong disiplin bukan semata- mata karena paksaan tetapi mereka disiplin berdasarkan kesadaran sendiri.

2. Disiplin korektif

Yaitu kegiatan yang diambil untuk menangani pelanggaran terhadap aturan- aturan dan mencoba menghindari pelanggaran- pelanggaran lebih lanjut
3. Disiplin Progresif

Yaitu penerapan suatu kebijakan dengan memberikan hukuman yang lebih berat terhadap pelanggaran yang berulang. Tujuannya untuk memberikan kesempatan kepada karyawan untuk mengambil tindakan hukuman yang lebih serius.

Menurut Siagian (2001: 181) disiplin merupakan sutu bentuk pelatihan yang berusaha memperbaiki dan membentuk pengetahuan, sikap dan perilaku karyawan sehingga karyawan tersebut secara suka rela berusaha keras secara kooperatif dengan karyawan yang lain serta meningkatkan prestasi kerjanya. Disiplin kerja yang tinggi merupakan harapan perusahaan kepada para karyawaanya, oleh karena itu masalah ini perlu penanganan intensif dari semua pihak yang terlibat dalam suatu perusahaan untuk mencapai tujuan perusahaan tersebut. Dalam penangangan pelanggaran yang dilakukan karyawan, perlu adanya sikap dan kebijakan yang tegas guna mengoreksi, memperbaiki, dan menghindari terulang kembalinya pelanggaran di masa- masa mendatang.

Hal- hal yang perlu diperhatiakan oleh pimpinan untuk memelihara disiplin karyawannya menurut Widodo (2001: 98) antaran lain:

1. Memberi koreksi terhadap berbagai kekurangan dan atau kekeliruan.

2. Memberi reward atau penghargaan walaupun dengan kata- kataterhadap prestasi yang diraih oleh bawahannya.

3. Mengadakan komunikasi dengan bawahan pada waktu senggang yang diarahkan pimpinan. 
4. Mengubah pengetahuan bawahan sehingga dapat meningkatkan nilai dirinya untuk kepentingan perusahaan.

5. Memberikan kesempatan berdialog demi meningkatkan keakraban antara pimpina dan bawahan.

\section{Komunikasi}

\section{Pengertian Komunikasi}

Komunikasi merupakan salah satu fungsi dari manajemen yang penting. Komunikasi adalah penyampaian informasi dari seseorang kepada orang lain. Komunikasi juga merupakan pertukaran ide- ide dan informasi dua arah yang menuju tercapainya pengertian bersama (Thoha, 2004: 78). Komunikasi sangat dibutuhkan dalam penyediaan pedoman standar etika perusahaan dan aktivitas yang membentuk kesatuan antara wilayah fungsional dalam bisnis. Komunikasi adalah penyampaian berbagai macam perasaan, sikap, dan kehendak baik secara langsung maupun tidak langsung baik secara sadar ataupun tidak sadar.

$$
\text { Wursanto }
$$$$
\text { (2002: }
$$

mendefinisikan komunikasi sebagai proses penyampaian informasi dari sumber kepada penerima untuk menjalin pengertian dan merubahtingkah laku penerima seperti yang diinginkan oleh sumber. Komunikasi dimaksudkan dapat memberi kejelasan tentang fungsi dan peran masing- masing karyawan, sehingga terjadi saling pengertian antara pemberi dan penerima informasi. Kreitner dan Kinicki (2005: 198) mendefinisikan sebagai pertukaran informasi antara pengirim dan penerima dan kesimpulan persepsi makna antara individu- individu yang terlibat. Hal ini menyatakan bahwa komunikasi merupakan proses dua arah yang berisi elemen- elemen yang berhubungan secara berurutan. Seorang manajer dituntut untuk dapat mengerti proses ini sehingga dapat menganalisa pola komunikasi mereka sendiri sebagai rancangan program komunikasi yang dapat memenuhi kebutuhan perusahaan.

Proses komunikasi dapat dilakukan dengan model saluran yaitu sebuah model yang menggambarkan komunikasi seperti sebuah pipa saluran dimana informasi dan makna ditransfer dari individu ke individu. Model lainnya yang berkembang saat ini adalah psoses informasi sosial dimana dalam proses ini penerima pesan dituntut untuk mengartikan suatu pesan dengan cara memproses informasi yang telah diterima secara kognitif. Selain itu ada juga komunikasi perseptual dimana penerima informasi menciptakan makna sendiri dalam benak mereka.

Elemen- elemen komunikasi dalam model konseptual antara lain:
a. Pengirim
b. Pengkodean
c. Pesan
d. Penguraian kode
e. Mencipta makna
f. Umpan balik/ respon
g. Gangguan 


\section{Pentingnya Komunikasi dalam Perusahaan}

Kelancaran komunikasi mendorong karyawan untuk lebih meningkatkan kreativitas dan semangat kerja sesuai dengan batas kemampuan masingmasing. Wursanto (2002: 60) menyatakan bahwa komunikasi dalam organisasi mempunyai fungsi sebagai berikut:

a. Menimbulkan rasa kesetiakawanan dan loyalitas antara pimpinan dan karyawan.

b. Meningkatkan gairah kerja karyawan.

c. Meningkatkan moral dan disiplin karyawan.

d. Semua jajaran pimpinan dapat mengetahui keadaan bidang yang menjadi tugasnya sehingga akan berlangsung pengendalian operasional yang efisien.

e. Karyawan dapat mengetahui kebijakan, peraturan, ketentuan yang telah ditetapkan oleh pimpinan perusahaan.

f. Semua informasi, keterangan yang dibutuhkan oleh karyawan dapat dengan cepat dan tepat diperoleh.

g. Meningkatkan rasa tanggung jawab semua karyawan.

h. Menimbulkan saling pengertian diantara karyawan.

i. Meningkatkan kerjasama diantara karyawan.

j. Meningkatkan semangat korp atau esprit de corp di kalangan para karyawan.

\section{Unsur-unsur Komunikasi}

Charles dalam Wursanto (2002: 157) mengatakan bahwa komunikasi mengandung 5 unsur yaitu:

a. Komunikator, yaitu memberi berita, dalam hal ini adalah orang yang berbicara, pengirim berita atau orang yang memberitakan.

b. Menyampaikan berita, dalam hal ini dapat dilakukan dengan cara mengatakan, mengirim atau menyiarkan.

c. Berita- berita yang disampaikan, dapat dalam bentuk perintah, laporan, atau saran.

d. Komunikan, yaitu orang yang dituju, pihak penjawabatau para pengunjung, dengan kata lain orang yang menerima berita.

e. Tanggapan atau reaksi, dalam bentuk jawaban atau reaksi.

Kelima unsur komunikasi tersebut merupakan kesatuan yang utuh, apabila salah satu unsur tidak ada maka komunikasi tidak akan terjadi. Dengan demikian masing- masing unsur saling berhubungan dan ada saling ketergantungan. Keberhasilan komunikasi ditentukan oleh semua unsur tersebut.

\section{Hambatan Komunikasi}

Komunikasi dalam

perusahaan dapat mengalami kegagalan apabila proses komunikasi terganggu. Wursanto (2002: 171) menyebutkan beberapa hambatan yang bersifat teknis, yaitu hambatan yanf disebabkan oleh berbagai faktor, seperti: 
a. Kurangnya sarana dan peranan yang diperlukan dalam proses komunikasi.

b. Penguasaan teknik dan metode komunikasi yang tidak sesuai.

c. Kondisi fisik yang tidak memungkinkan terjadinya proses komunikasi.

\section{Penelitian Terdahulu Yang Relevan}

Penelitian Budi Santoso (2016) dengan judul Pengaruh Pemberian Insentif dan Kompetensi Terhadap Kinerja Karyawan PG. Madukismo Yogyakarta, Hasil penelitiannya menunjukkan bahwa terdapat pengaruh positif dan signifikan pemberian insentif dan kompetensi secara individu maupun bersama-sama terhadap kinerja karyawan PG. Madukismo Yogyakarta.

Ferina Sukmawati [2008] dengan judul Pengaruh Kepemimpinan,Lingkungan kerja ,dan kompetensi terhadap kinerja karyawan di PT.Pertamina,hasil penelitiannya terdapat pengaruh positif dan signifikan kepemimpinan,lingkungan kerja dan kompetensi secara individu maupun bersama-sama terhadap kinerja karyawan.

Fitri Cinta Utami (2014) dengan judul Pengaruh kepemimpinan, komunikasi, disiplin kerja dan lingkungan kerja terhadap kinerja karyawan (studi kasus pada kantor BAPPEDA Kabupaten Sukoharjo) hasil penelitiannya juga menunjukkan terdapat pengaruh positif dan signifikan secara individu maupun bersamasamakepemimpinan, komunikasi, disiplin kerja dan lingkungan kerja terhadap kinerja karyawan.

\section{METODOLOGI PENELITIAN}

Penelitian ini menggunakan data primer yang diperoleh dari karyawan bagian sewing PT.Pelita Tomangmas Karanganyar. Metode pengumpulan data yang digunakan adalah metode angket/kuesioner dengan 50 karyawan sebagai responden. Teknik pengambilan sample yang digunakan adalah random sampling dengan metode convenionce sampling. Metode analisis data yang digunakan antara lain : uji instrument (validitas dan reliabilitas) dan uji hipotesis (analisis regresi liner berganda, uji t, uji $\mathrm{f}$ dan koefisien determinasi $\left(\mathrm{R}^{2}\right)$.

\section{Hipotesis}

Sugiono (2008: 93) menyatakan bahwa "hipotesis merupakan jawaban sementara terhadap rumusan masalah penelitian, oleh karena itu rumusan masalah biasanya disusun dalam bentuk kalimat pertanyaan.'Hipotesis dalam penelitian ini adalah :

1. Diduga ada pengaruh secara simultan dan signifikan antara insentif, disiplin kerja, dan komunikasi terhadap kinerja karyawan bagian sewing PT.Pelita Tomangmas Karanganyar.

2. Diduga ada pengaruh positif dan signifikan insentif terhadap kinerja karyawan bagian sewing PT.Pelita Tomangmas Karanganyar..

3. Diduga ada pengaruh positif dan signifikan disiplin kerja terhadap kinerja karyawan bagian sewing PT.Pelita Tomangmas Karanganyar.

4. Diduga ada pengaruh positif dan signifikan komunikasi terhadap kinerja karyawan bagian sewing PT.Pelita Tomangmas Karanganyar. 


\section{HASIL PENELITIAN}

HasilAnalisis deskriptif menunjukkan bahwa sebagian besar responden berjenis kelamin perempuan $(90 \%)$. Semua data dari penyebaran kuesioner telah lolos uji instrument.

Hasil uji asumsi klasik:

1. Uji Normalitas

Berdasarkan hasil perhitungan uji Kolmogorov Smirnov dapat diketahui bahwa Nilai Asymp. Sig. (2-tailed) ternyata lebih besar dari $\alpha$ ( $\mathrm{p}>0,05)$, maka dapat disimpulkan bahwa sebaran data nya normal.

2. Uji Multikolinieritas

\begin{tabular}{|l|c|c|}
\hline \multicolumn{1}{|c|}{ Variabel } & $\begin{array}{c}\text { Toler } \\
\text { ansi }\end{array}$ & VIF \\
\hline \hline Insentif & 0,569 & 1,756 \\
Dis.Kerja & 0,547 & 1,827 \\
Komunikasi & 0,621 & 1,610 \\
\hline
\end{tabular}

Berdasarkan tabel diatas dapat disimpulkan bahwa model regresi tersebut tidak terjadi multikolinieritas karena nilai VIF $<10$ dan Tolerasi > 0,1 .

3. Uji Heteroskedastisitas

\begin{tabular}{|l|l|}
\hline \multicolumn{1}{|c|}{ Variabel } & $t_{\text {hitung }}$ \\
\hline \hline Insentif & 0,568 \\
Dis.Kerja & 0,458 \\
Komunikasi & 0,942 \\
& \\
& \\
\hline
\end{tabular}

Berdasarkan tabel diatas nampak bahwa semua variabe bebas memiliki nilai $\mathrm{p}$ diatas 0,05 sehingga semua variabel bebas tersebut bebas dari masalah heteroskedastisitas.

4. Uji Autokorelasi

\begin{tabular}{|l|l|l|}
\hline $\mathrm{dU}$ & $\mathrm{Dl}$ & Durbin Watson \\
\hline 1,613 & 1,236 & 1,892 \\
\hline
\end{tabular}

Berdasarkan tabel diatas terlihat bahwa nilai DW 1,892 lebih besar dari batas atas (dU) yakni 1,613 dan kurang dari (4-dU) $4-1,613=2,387$ dapat disimpulkan bahwa tidak terdapat autokorelasi.

Untuk pengujian uji $\mathrm{f}$ diperoleh hasil bahwa nilai $F_{\text {hitung }}(46,710)>F_{\text {tabel }}$ $(2,81)$ dengan probabilitas sebesar $0,000$ ( $p<0,05)$. Hal ini berarti Fhitung berada pada daerah Ho ditolak, yang artinya terdapat pengaruh yang signifikan antara variable independent (insentif, disiplin kerja, dan komunikasi) secara simultan terhadap variable dependen (kinerja karyawan). Model persamaan regresi yang dapat disusun adalah sebagai beikut:

$\mathrm{Y}=3,665+0,416 \mathrm{X}_{1}+0,207 \mathrm{X}_{2}+$ $0,247 X_{3}$

Dari hasil uji $\mathrm{t}$ diperoleh hasil insentif mempunyai pengaruh positif signifikan secara individual terhadap variable kinerja karyawan. Hal ini terbukti dari nilai $t_{\text {hitung }}$ $(5,697)>t_{\text {tabel }}(2,013)$ dengan nilai signifikansi $<\alpha(0,05)$. Disiplin Kerja juga berpengaruh positif signifikan terhadap kinerja karyawan. Hal ini dikarenakan nilai $t_{\text {hitung }}(2,164)>t_{\text {tabel }}(2,013)$ dengan nilai signifikansi $<\alpha(0,05)$. Demikian juga komunikasi berpengaruh positif signifikan terhadap kinerja karyawan. Hal ini 


\begin{abstract}
dikarenakan nilai $t_{\text {hitung }}(2,551)>$ $t_{\text {tabel }} \quad(2,013)$ dengan nilai signifikansi $<\alpha(0,05)$. Hasil analisis dalam penelitian ini diperoleh nilai $\mathrm{R}^{2}$ sebesar 0,753 $(75,3 \%)$. Hal ini berarti bahwa variable independent (insentif, disiplin kerja, dan komunikasi) mampu memberikan sumbangan pengaruh sebesar $75,3 \%$ terhadap variable dependen (kinerja karyawan). Sedangkan sisanya sebesar $24,7 \%$ dipengaruhi oleh variable lain diluar penelitian ini seperti kepemimpinan, kompetensi, budaya organisasi, dan lingkungan kerja
\end{abstract}

\section{KESIMPULAN}

Dari hasil pembahasan mengenai pengaruh insentif, disiplin kerja dan komunikasi terhadap kinerja karyawan bagian sewing PT.Pelita Tomangmas Karanganyar dapat diambil beberapa kesimpulan sebagai berikut:

1. Hasil pengujian menunjukkan bahwa insentif, disiplin kerja, dan komunikasi berpengaruh secara simultan terhadap kinerja karyawan bagian sewing PT.Pelita Tomangmas Karanganyar yang ditunjukkan dari hasil Uji $F$ sebesar 46,710 artinya bahwa apabila diberikan insentif bagim karyawan yang memenuhi kriteria, disiplin kerja terus ditingkatkan serta membangun komunikasi yang baik diantara semua elemen perusahaan maka kinerja karyawan juga akan mengalami peningkatan.

2. Insentif berpengaruh positif signifikan terhadap kinerja karyawan bagian sewing PT.Pelita Tomangmas Karanganyar, yang ditunjukkan dari nilai hasil uji t sebesar $(5,697)$ artinya bahwa adanya sistem pemberian insentif bagi karyawan yang dapat melaksanakan tugasnya dengan baik dan tepat waktu maka secara otomatis akan meningkatkan kinerja karyawan tersebut.

3. Disiplin kerja berpengaruh positif signifikan terhadap kinerja karyawan bagian sewing PT.Pelita Tomangmas Karanganyar, yang ditunjukkan dari nilai hasil uji t sebesar $(2,164)$ artinya bahwa apabila tingkat kedisiplinan karyawan, baik disiplin waktu, disiplin kerja dditingkatkan maka hal ini akan meningkatkan kinerja karyawan.

4. Komunikasi berpengaruh positif signifikan terhadap kinerja karyawan, yang ditunjukkan dari nilai hasil uji $\mathrm{t}$ sebesar $(2,551)$.

5. Koefisien determinasi $R$ Square $\left(R^{2}\right)$ pada penelitian ini adalah 0,753 dapat disimpulkan bahwa variabel-variabel bebasnya memberikan sumbangan positif yaitu sebesar 75,3 \% terhadap variabel terikat sedangkan $24,7 \%$ dipengaruhi oleh faktor lain seperti kepemimpinan, kompetensi, budaya organisasi, dan lingkungan kerja.

\section{Saran}

1. Hendaknya sistem pemberian insentif yang sudah berjalan selama ini dipertahankan terus sehingga karyawan akan termotivasi untuk bekerja lebih baik lagi, dan diperjelas kriteria pegawai yang berhak mendapatkan insentif tersebut. 
2. Disiplin kerja harus terus ditingkatkan bagi semua elemen perusahaan dan pimpinan juga perlu mmberikan reward atau penghargaan bagi karyawan yang tertib dan disiplin walaupun hanya dengan kata- kata pujian karena hal itu dapat mendorong semangat kerja karyawan. Bagi yang melanggar aturan atau tata tertib perusahaan, wajib diberi punishment atau sanksi yang tegas agar tidak ditiru oleh karyawan yang lain.

3. Komunikasi antara pimpinan dengan bawahan maupun antar sesama karyawan yang sudah berjalan selama ini harus terus ditingkatkan agar karyawan merasa semakin nyaman dalam bekerja karena ada kedekatan antar komponen perusahaan, yang pada akhirnya akan meningkatkan kinerja karyawan.

4. Hendaknya kinerja pegawai yang sudah terlaksana dengan baik dan terkoordinir terus ditingkatkan melalui monitoring dan evaluasi atau penilaian secara berkala.

\section{DAFTAR PUSTAKA}

Arikunto Suharsimi, 2006, Prosedur Penelitian Suatu Pendekatan Praktek, Edisi Revisi VI, PT. Rineka Cipta, Jakarta.

Budi Santoso, 2016. Pengaruh Pemberian insentif dan Kompetensi Terhadap Kinerja Karyawan pg. Madukismo Yogyakarta,UNY, Yogyakarta.

Dessler, Gary, 2009. Manajemen Sumber Daya Mnusia. Jilid Dua. Alih
Bahasa Agus Dharma. Jakarta : Erlangga Mathis dan Sakson

Hariandja, Marihot Tua Efendi. (2005), Manajemen sumber Daya Manusia: Pengadaan, Pengembangan, Pengkompensasian, dan Peningkatan Produktivitas Pegawai. Jakarta: PR Grasindo

Hasibuan, 2009. Manajemen Sumber Daya Manusia, Bumi Aksara, Jakarta.

Istiatin, 2015, Modul Metodologi Penelitian, Unibapress ,Surakarta.

Kezia, Alfarika. 2015. Pengaruh Disiplinan Kerja dan Komunikasi Organisasi Terhadap Kinerja Karyawan pada Astra Kredit Companies Cabang Samarinda.. Ejurnal Ilmu Administrasi Bisnis Vol. 3, Nomor 2. Universitas Mulawarman. Samarinda.

Komang, dkk. 2008. Perilaku Keorganisasian, Edisi Pertama, Graha Ilmu. Yogyakarta.

Kreitner dan Kinichi. 2005. Perilaku Organisasi. Salemba Empat. Jakarta

Mangkunegara, Anwar Prabu, 2007. Manajemen Sumber Daya Manusia Organisasi, Cetakan Ketujuh, PT Remaja Rosdakarya Offset, Bandung.

Manulang, M, 2002. Manajemen Personalia Edisi 4, Edisi I BPFE, Yogyakarta. 
Maryam, Siti. 2012. Statistik Induktif .Surakarta. Uniba Press.

Panggabean, Mutiara, 2005. Manajemen Sumber Daya Manusia, Cetakan Pertama, Ghalia Indonesia, Bogor.

Pawenang, Supawi dan Eni Kustiyah, 2011, Pengantar Ekonometrika, Idea Press, Yogyakarta.

Robert L. Mathis \& John H. Jackson, 2006. Human Resources Management, Edisi sepuluh, Penerbit Salemba Empat. Jakarta.

Robbins, Stephen. 2011, Perilaku Organisasi, Edisi Kedelapan, Versi Bahasa Indonesia, Jilid II Perason Education Asia. PT. Prengallindo, Jakarta.

Siagian, S.P. 2002. Kiat Meningkatkan Produktifitas Kerja. Jakarta: Rineka Cipta.

Simamora Henry (2006). Manajemen Sumber Daya Manusia Edisi Ke-3. Yogyakarta: STIE YKPN

Sugiyono. 2008. Metode Penelitian Kuantitatif Kualitatif dan R\& D. Bandung: Alfabeta.

Sutrisno Edy, 2009, Manajemen Sumber Daya Manusia. Kencana Pernada Media Group. Jakarta.

Thoha, Miftah. 2004. Kepemimpinan dalam Manajemen. Jakarta : Gramedia Wangso, Jiwo dan Brotoharsojo, Hartanto. (2003), Merit sistem. PT. Raja Grafindo Persada. Jakarta
Wursanto, Ig. 2002. Dasar- dasar Ilmu Organisasi. Yogyakarta: Penerbit Andi Offset. 